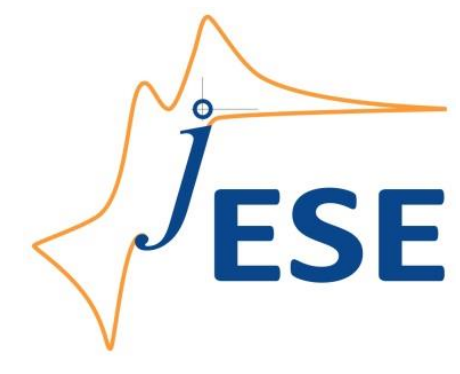

Open Access : : ISSN 1847-9286

www.jESE-online.org

Original scientific paper

\title{
Electrocoagulation of textile wastewater containing a mixture of organic dyes by iron electrode
}

Borislav N. Malinovic ${ }^{1,}$, Miomir G. Pavlovic ${ }^{2}$,Tijana Djuricic ${ }^{1}$

${ }^{1}$ University of Banja Luka, Faculty of Technology, Stepe Stepanovića 73, 78000 Banja Luka, Bosnia

and Herzegovina

${ }^{2}$ University of Belgrade, ICTM-CEH, Njegoševa 12, Belgrade, Serbia

${ }^{\otimes}$ Corresponding author: borislav.malinovic@tf.unibl.org; Tel.: +387-51-434-365; Fax: +387-51-465-032

Received: January 13, 2017; June: May 5, 2017; Accepted: June 6, 2017

\begin{abstract}
This study focused on testing the efficacy of iron (Fe) electrode in an electrochemical treatment (electrocoagulation) of wastewater containing a mixture of organic dyes. The mixture consists of the following azo dyes: Acid Black 194, Acid Black 107 and Acid Yellow 116. The present organic dyes are toxic, cause skin and eye irritation and are extremely dangerous to aquatic organisms. The study was conducted on a synthetic wastewater prepared in a laboratory electrochemical reactor. During the research, the impact of the current density, various concentrations of dye and supporting electrolyte, electrolysis duration and pulsed current regime were tracked. The results are shown through color removal efficiency, chemical oxygen demand (COD) removal efficiency, current efficiency, and specific energy consumption. At the initial concentration of dye $(\gamma=200 \mathrm{mg} / \mathrm{L})$ and concentration of supporting electrolyte $\left(\gamma_{\mathrm{NaCl}}=1 \mathrm{~g} / \mathrm{L}\right)$ the color removal efficiency of $80.64 \%$ was achieved for 420 seconds of treatment $\left(j=10 \mathrm{~mA} / \mathrm{cm}^{2}\right)$. At the initial concentration of dye $(\gamma=50 \mathrm{mg} / \mathrm{L})$ and $\gamma_{\mathrm{NaCl}}=8 \mathrm{~g} / \mathrm{L}$, the color removal efficiency of $96.01 \%$ was attained for 300 seconds of treatment $\left(j=10 \mathrm{~mA} / \mathrm{cm}^{2}\right)$.
\end{abstract}

Keywords

organic dyes, electrochemical treatment; removal efficiency

\section{Introduction}

The textile industry is one of the world's biggest polluters according to the amount of wastewater where the most problems are generated by the textile dyeing process. General characteristics of textile dyeing wastewaters are related to, a high content of organic matter, presence of heavy metals and high coloration. As the annual global production of synthetic dyes exceeded 900,000 tonnes in 2009, it is expected to be well over a million tonnes per annum at 
present [1]. Since nearly two-thirds $(60-70 \%)$ of all synthetic dyes are azo dyes [2], azo dyes are considered as the most commonly used dyestuff in the dye industry.

During the dyeing processes in textile industry, up-to $50 \%$ of the used dyes may not be fixed to their fibre substrates and hence may be washed out to form highly coloured effluent streams [3]. According to $\mathrm{Yu}$ and Wen [4], many synthetic dyes belong to xenobiotic chemicals that are degraded with difficulty in nature. Difficult degradation of synthetic dyes is the main reason why their removal from aqueous effluents from the textile industry has received a considerable environment research attention [4]. Due to their complex structure and synthetic origin, azo dyes are difficult to be decolourized, what imposed an obligation for their removal from industrial effluents before being disposed into enviroment. Many studies have shown that azo dyes contribute to mutagenic activity of ground and surface waters polluted by textile effluents $[5,6]$. Also, discharge of azo dyes into surface water leads to aesthetic problems and obstructs light penetration and oxygen transfer into water bodies, affecting thus the aquatic life. Thus, the removal of color from textile effluents has grown as a topic of major concern [7].

In this paper we used a mixture that is used for dyeing polyamide fibers. The mixture contained synthetic dyes that belong to azo dyes and heavy metals cobalt and chromium (Co and $\mathrm{Cr}$ IIIcomplex). An extensive literature, reporting the characteristics and applications of most important conventional technologies developed for this purpose, including physico-chemical and chemical methods, advanced oxidation processes (AOPs), adsorption, microbiological treatments, enzymatic decomposition and electrochemical technologies, has already been published [8-13]. Here, an increasingly present electrocoagulation (EC) treatment for removing color from wastewater is described. EC treatment implies formation of coagulants in situ by electrolytic dissolution of the anode made from either aluminum or iron. During the EC process, the anode leads to the formation of metal ions, while evolution of hydrogen gas at the cathode carries the flocculated particles to the surface of the water. The chemical reactions taking place at the anode are given as follows [14]:

For iron anode:

$\mathrm{Fe}-2 \mathrm{e}^{-} \rightarrow \mathrm{Fe}^{2+}$

at alkaline conditions:

$\mathrm{Fe}^{2+}+2 \mathrm{OH}^{-} \rightarrow \mathrm{Fe}(\mathrm{OH})_{2}$

at acidic conditions:

$4 \mathrm{Fe}^{2+}+\mathrm{O}_{2}+2 \mathrm{H}_{2} \mathrm{O} \rightarrow 4 \mathrm{Fe}^{3+}+4 \mathrm{OH}^{-}$

In addition, there is oxygen evolution reaction:

$2 \mathrm{H}_{2} \mathrm{O}-4 \mathrm{e}^{-} \rightarrow \mathrm{O}_{2}+4 \mathrm{H}^{+}$

The reaction at the cathode is:

$2 \mathrm{H}_{2} \mathrm{O}+2 \mathrm{e}^{-} \rightarrow \mathrm{H}_{2}+2 \mathrm{OH}^{-}$

The EC treatment has received great attention in recent years due to its unique features, such as versatility, energy efficiency, automation and cost effectiveness [12,15]. Alaton et al. [16] have proven the effectiveness of using EC as a method of removing color from wastewater of textile industry. According to their study, EC proved to be a very promising alternative treatment which is increasingly used in wastewater treatment. Simulated wastewater polluted by acidic dyes has 
already been treated by EC using aluminum and steel electrodes. The results showed that the COD removal efficiency, color removal efficiency and the production of sludge were affected by the current intensity, concentration of supporting electrolyte and the initial $\mathrm{pH}$-value. EC with aluminum electrodes is found able to remove almost $90 \%$ of color and reduce COD-value to $40 \%$, while with steel electrodes, COD value was reduced to about $50 \%$ [16].

The phenomenon of electrode passivation has limited further application of EC treatment. Application of pulsed current regime, also known as pulsed electrocoagulation - PE (it uses the interactions of electrochemical technology and polarity reversal in an electrical field), brought a significant impact on the electrochemical processes though higher activity and efficiency during the process [17-20]. Hence, the development of PE was explored in recent years [20].

\section{Experimental}

Electrochemical batch reactor (Fig. 1) of capacity $500 \mathrm{~cm}^{3}$ is made of polypropylene and has a possibility of constant mixing $(500 \mathrm{rpm} / \mathrm{min})$. The reactor contains two electrodes of the same dimensions (area), $P=32.8 \mathrm{~cm}^{2}$, put at a distance, $d=30 \mathrm{~mm}$. Electrodes were connected to a digital power source (Atten, APS3005SI; 30V, 5A). Pulsed current regime is provided by a generator of variable periodic current (Selekt-automatika, Serbia).

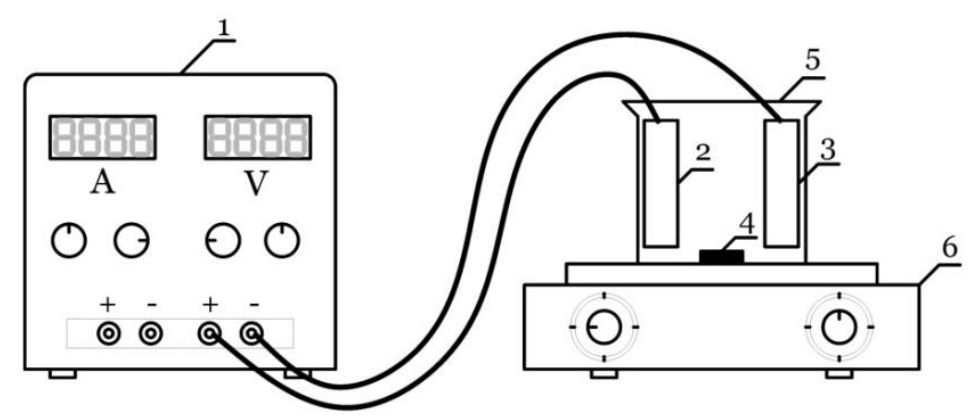

Figure 1. Schematic view of electrochemical reactor: 1 - source of electric power; 2 -anode; 3 -cathode; 4 - magnetic stir bar; 5 - electrochemical cell; 6-magnetic stirrer

Electrode materials were metals of known compositions: iron (EN10130-91; max. 0,08 \% C, max. $0.12 \% \mathrm{Cr}$, max. $0.45 \% \mathrm{Mn}$, max. $0.60 \% \mathrm{Si}$ ) and stainless steel (EN 1.4301/AISI 304; max. $0.07 \%$ C, $18.1 \% \mathrm{Cr}, 8.2 \% \mathrm{Ni})$. Attention was put to the appropriate relations between electrode surface area $\left(A_{s}\right)$ and volume $(V)$ of the reactor. For used electrochemical reactor that relation, $\left(A_{s} / \mathrm{V}\right) /\left(\mathrm{m}^{2} / \mathrm{m}^{3}\right)$, is $16.4 \mathrm{~m}^{2} / \mathrm{m}^{3}$, which is in compliance with recommendations given by Mameri et al. [21] for current density values of 10 to $200 \mathrm{~A} / \mathrm{cm}^{2}$. All experiments were performed at an initial temperature of sample $t=20^{\circ} \mathrm{C}$. Before each treatment, current density was set at the desirable value and electrodes were mechanically cleaned and washed with detergent and acetone in order to remove surface grease. Electrode surfaces were additionally cleaned by emerging ( $5 \mathrm{~min}$ ) in diluted (1:2) solution of $\mathrm{HCl}$ before each treatment.

In present experiments, commercially available $99.5 \%$ sodium chloride, $\mathrm{NaCl}, 35 \%$ hydrochloric acid, $\mathrm{HCl}$, acetone, $\left(\mathrm{CH}_{3}\right)_{2} \mathrm{CO}$ (Lachner, Czech) and "Ostalan Black SR" dye (Synthesia a.s., Czech) were used. "Ostalan Black SR" is a mixture of synthetic dyes that belong to the group of azo dyes. According to Safety Data Sheet (SDS) [22], "Ostalan Black SR" consists of the following azo dyes: Acid Black 194 (the mixture containing 40-50\%), Acid Black 107 (mixture contains 40-50 \%) and Acid Yellow 116 (mixture contains $>1 \%$ ). All mentioned dyes are potentially harmful to humans and the environment and labeled as very toxic to living organisms and harmful to aquatic organisms [22]. 
COD was measured by the closed spectrophotometric method on COD Reactor (Hach, USA), colorimeter (COD CheckltDirect, Lovibond, Germany) by standard cuvette (Test Tube MR, Lovibond, Germany), and the dye concentration was determined spectrophotometrically $\left(\lambda_{\max }=573 \mathrm{~nm}\right)$ on UV-VIS spectrophotometer (Perkin Elmer, Lambda 25) according to standard methods [23]. Measurement in the pulsed current regime is defined by the cathode current density $\left(j_{k}\right)$, time cathode deposition $\left(t_{k}\right)$, anodic current density $\left(j_{\mathrm{a}}\right)$, and time of anodic dissolution $\left(t_{\mathrm{a}}\right)$. The period of pulsed current waves, $(T)$, is the sum of the time of cathode deposition $\left(t_{k}\right)$ and time of anodic dissolution $\left(t_{\mathrm{a}}\right)[24]$

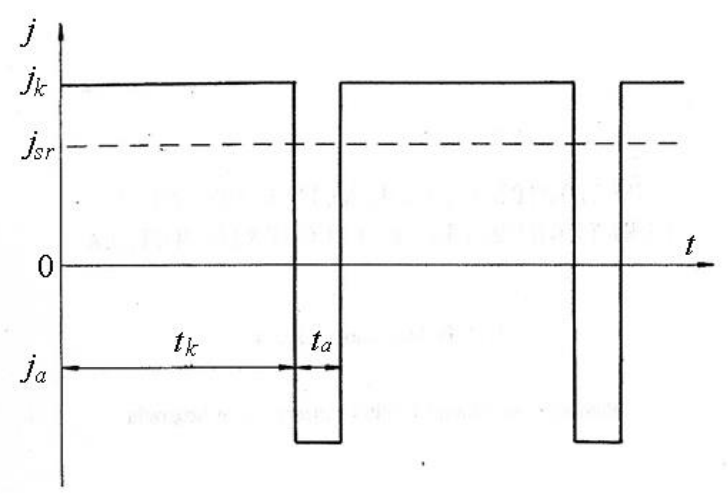

Figure 2. Schematic view of PE [24]

\section{Results and discussion}

Results of the electrochemical color removal are showed through decrease of mass concentration, $\gamma /(\mathrm{mg} / \mathrm{L})$, and color removal efficiency, $E_{u} / \%$ defined as

$$
E_{\mathrm{U}} / \%=\frac{\gamma_{i}-\gamma_{\mathrm{f}}}{\gamma_{\mathrm{i}}} 100
$$

where $\gamma_{\mathrm{i}}$ and $\gamma_{\mathrm{f}}$ are initial and final dye concentrations, $\mathrm{mg} / \mathrm{L}$.

Current efficiency, $\eta_{1}$, has been calculated according to the following equation (10):

$$
\eta_{\mathrm{I}} / \%=\frac{\left(\mathrm{COD}_{i}-\mathrm{COD}_{\mathrm{f}}\right) F \mathrm{~V}}{8 I t} 100
$$

In Eq. (10), $C O D_{i}$ and $C O D_{f}$ are initial and final chemical oxygen demand (COD) values, $F$ is the Faraday constant, $V$ is the volume of solution (wastewater), 8 is constant, $l$ is the current intensity and $t$ is electrolysis duration.

Selection of electrodes (soluble or insoluble anode) depends primarily on the mechanism of electrolytic reaction and according to the literature data and previous research it plays the most important role [25]. In the case of EC, selection of electrode material is narrowed to the iron and aluminum electrodes, respectively.

Figure 3 shows the color removal efficiency at different current densities $\left(1 ; 2.5 ; 5 ; 10 \mathrm{~mA} / \mathrm{cm}^{2}\right)$ for the initial dye concentration, $\gamma_{0}=200 \mathrm{mg} / \mathrm{L}$, supporting electrolyte concentration, $\gamma_{\mathrm{NaCl}}=1 \mathrm{~g} / \mathrm{L}$, and electrolysis duration, $t=5 \mathrm{~min}$. At the current density of $j=10 \mathrm{~mA} / \mathrm{cm}^{2}, E_{\mathrm{u}}=67.75 \%$.

Change of current density to efficiency of color removal could be presented by the following equation.

$$
E_{\mathrm{u}}=18.832 \ln j+25.085
$$

During the study, $\mathrm{NaCl}$ has been used as the supporting electrolyte. Figure 4 shows the effect of $\mathrm{NaCl}$ concentration on color removal efficiency $\left(\gamma_{0}=200 \mathrm{mg} / \mathrm{L}\right)$. Duration of electrolysis for all concentrations of the supporting electrolyte was $t=5 \mathrm{~min}$ at $j=10 \mathrm{~mA} / \mathrm{cm}^{2}$. Figure 4 shows that 
removal efficiency is the highest at $\gamma_{\mathrm{NaCl}}=8 \mathrm{~g} / \mathrm{L}\left(E_{\mathrm{u}}=96.01 \%\right)$, and the lowest at $\gamma_{\mathrm{NaCl}}=1 \mathrm{~g} / \mathrm{L}$ $\left(E_{u}=85.3 \%\right)$. Change of the supporting electrolyte concentration to efficiency of color removal could be presented by the equation (12).

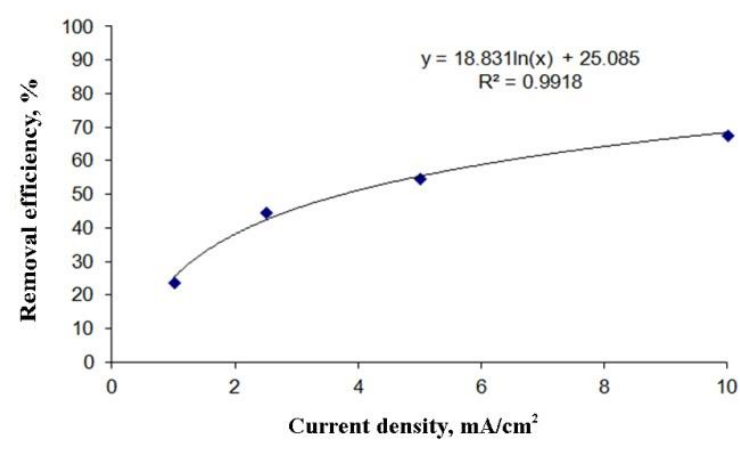

Figure 3. Effect of current density on color removal efficiency

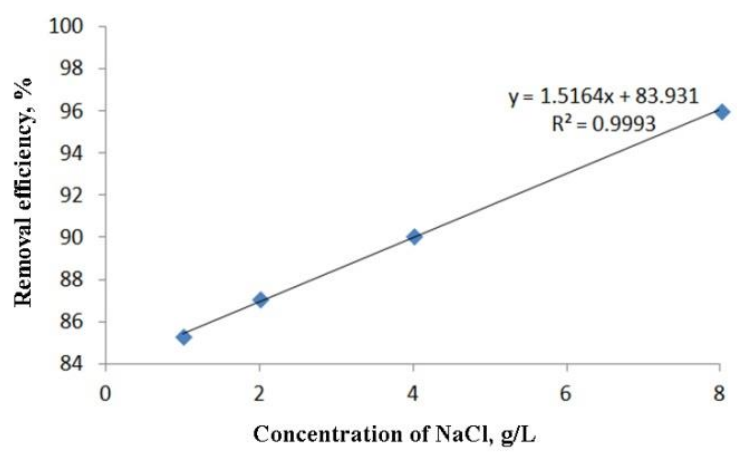

Figure 4. Effect of $\mathrm{NaCl}$ concentration on color removal efficiency

$$
E_{\mathrm{u}}=1.5164 \gamma_{\mathrm{NaCl}}+83.931
$$

Since there is a little difference in $E_{\mathrm{u}}$ between $\gamma_{\mathrm{NaCl}}=1 \mathrm{~g} / \mathrm{L}$ and $\gamma_{\mathrm{NaCl}}=8 \mathrm{~g} / \mathrm{L}$ observed, $\gamma_{\mathrm{NaCl}}=1 \mathrm{~g} / \mathrm{L}$ will be used in the further part of research.

At the current density, $j=1 \mathrm{~mA} / \mathrm{cm}^{2}$, electrolysis time duration, $t=5 \mathrm{~min}$, and the concentration of supporting electrolyte $\gamma_{\mathrm{NaCl}}=1 \mathrm{~g} / \mathrm{L}$, the removal efficiency is increased by reducing the initial concentration of dye, which is shown in Figure 5. Removal efficiency is the highest at dye concentration, $\gamma=50 \mathrm{mg} / \mathrm{L}\left(E_{\mathrm{u}}=85.3 \%\right)$ and the lowest at $\gamma=400 \mathrm{mg} / \mathrm{L}\left(E_{\mathrm{u}}=45.81 \%\right.$.). Effect of the initial concentration of dye to the removal efficiency could be presented by the equation (13).

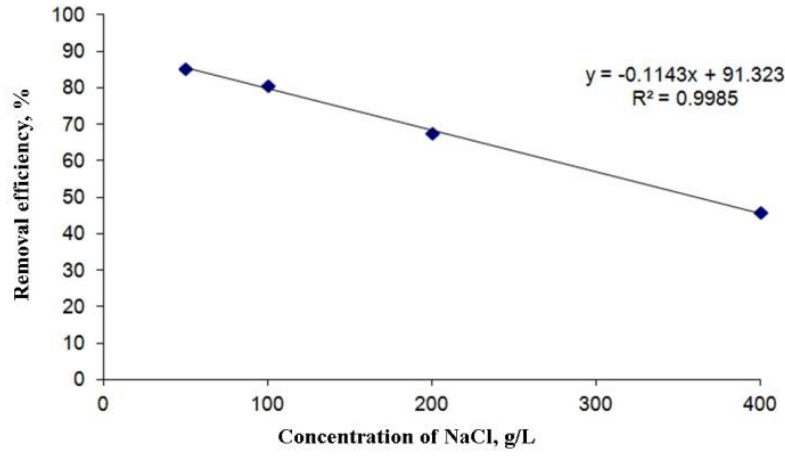

Figure 5. Efficiency of color removal for different initial concentrations of dye

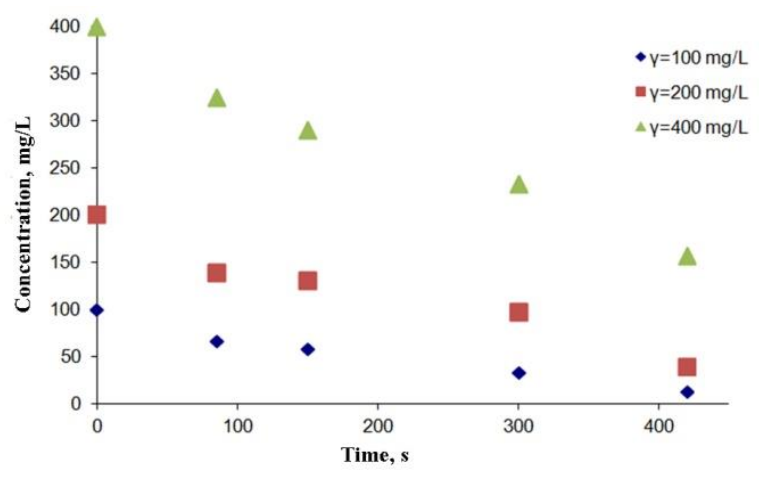

Figure 6. Effect of electrolysis duration on concentration decrease for different initial dye concentrations.

$$
E_{\mathrm{u}}=-0.1143 \gamma_{\text {dye }}+91.323
$$

Figure 6 shows the effect of electrolysis time on decrease of dye concentration for different initial dye concentrations $\left(j=10 \mathrm{~mA} / \mathrm{cm}^{2}, \gamma_{\mathrm{NaCl}}=1 \mathrm{~g} / \mathrm{L}\right)$. In Figure 7 , these results measured using the iron : iron ( $\mathrm{Fe}: \mathrm{Fe}$ ) electrode pair are compared with the results obtained at same conditions $\left(\gamma_{0}=400 \mathrm{mg} / \mathrm{L}, j=10 \mathrm{~mA} / \mathrm{cm}^{2}, \gamma_{\mathrm{NaCl}}=1 \mathrm{~g} / \mathrm{L}\right.$ ) using the stainless steel (SS) as the cathode material. Data in Figure 7 suggest that only slightly lower efficiency is achieved for the Fe : SS vs. Fe : Fe 
electrode pair. It seems, however, that the whole process is easier to maintain using the SS cathode, what can be explained by much better anti-corrosion properties of SS than Fe.

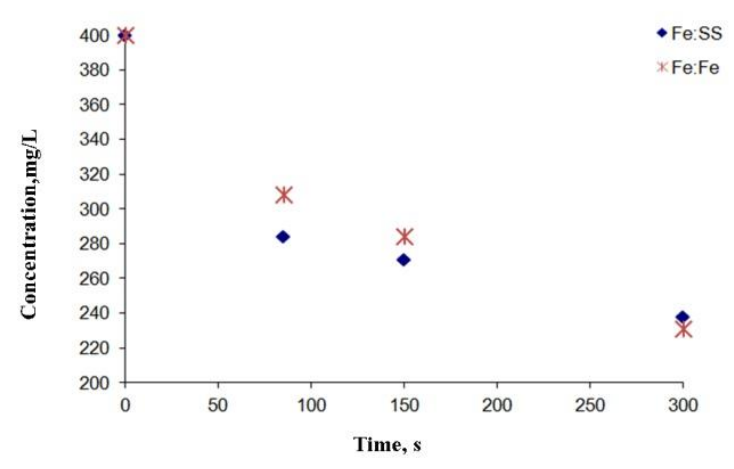

Figure 7. Effect of application different electrode pairs

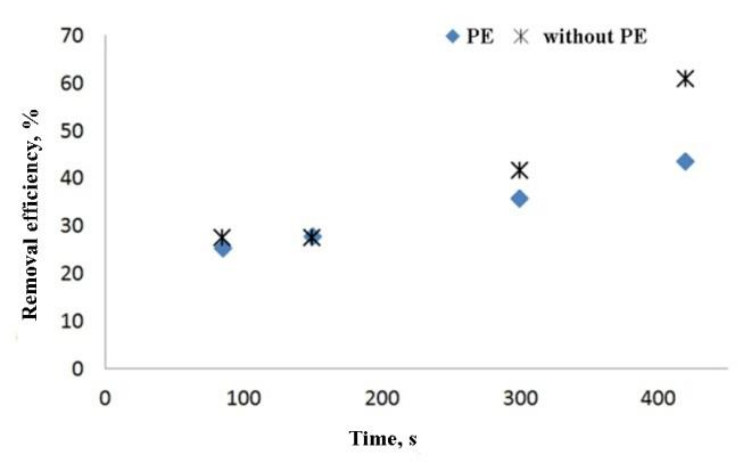

Figure 8. Color removal efficiency with and without application of $P E$

In the pulsed current regime (PE) the polarity of electrodes is reversed at a given time during the electrolysis (Fig. 2). Figure 8 shows differences between the efficiencies of color removal obtained by application PE and without PE in the same conditions $\left(j=5 \mathrm{~mA} / \mathrm{cm}^{2}, \gamma_{\mathrm{NaCl}}=1 \mathrm{~g} / \mathrm{L}, \gamma_{0}=400 \mathrm{mg} / \mathrm{L}\right.$, $\left.t_{k}=42 \mathrm{~s}, t_{a}=42 \mathrm{~s}\right)$. It is evident in Figure 8, that for longer treatment period, the removal efficiency is higher without applying PE. Contrary to already given predictions [23], such behavior could be a sign of no significant passivation and "dirtying" of the electrodes.

Effect of electrolysis duration $(85,150$ and $300 \mathrm{~s})$ at a current density $j=5 \mathrm{~mA} / \mathrm{cm}^{2}\left(\gamma_{0}=400 \mathrm{mg} / \mathrm{L}\right.$, $\left.\gamma_{\mathrm{NaCl}}=1 \mathrm{~g} / \mathrm{L}\right)$ and $j=10 \mathrm{~mA} / \mathrm{cm}^{2}\left(\gamma_{0}=200 \mathrm{mg} / \mathrm{L}, \gamma_{\mathrm{NaCl}}=1 \mathrm{~g} / \mathrm{L}\right)$ on COD values is shown in Figure 9. It is shown in Figure 9 that in both cases COD-values are linearly depended on time. For $t=300 \mathrm{~s}$, COD-value is reduced from the initial $385 \mathrm{mgO}_{2} / \mathrm{L}$ to $224 \mathrm{mgO}_{2} / \mathrm{L}\left(\gamma_{0}=400 \mathrm{mg} / \mathrm{L}\right)$, and from the initial $125 \mathrm{mgO}_{2} / \mathrm{L}$ to $56 \mathrm{mgO}_{2} / \mathrm{L}\left(\gamma_{0}=200 \mathrm{mg} / \mathrm{L}\right)$, what is in full agreement with the study Alaton et al. [16].

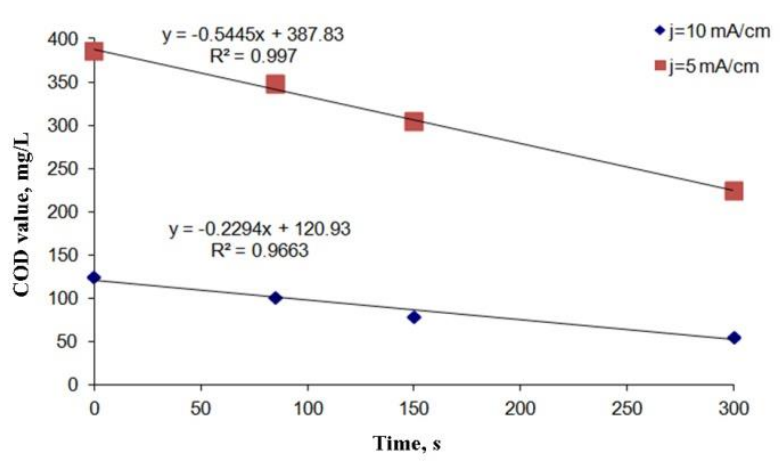

Figure 9. Effect of electrolysis duration on COD value

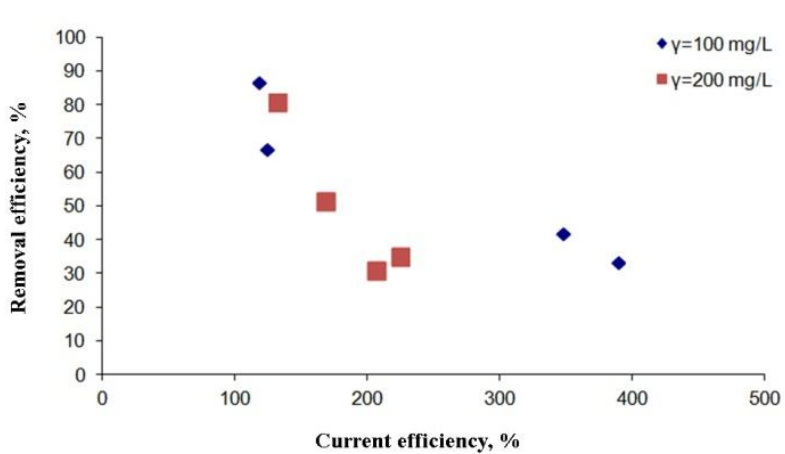

Figure 10. Removal efficiency vs. current efficiency

Changes of current efficiency on the color removal efficiency for different initial dye concentrations (100 and $200 \mathrm{mg} / \mathrm{L}$ ) are shown in Figure 10. Measurements were made at the current density of $j=10 \mathrm{~mA} / \mathrm{cm}^{2}$ and the concentration of supporting electrolyte $\gamma_{\mathrm{NaCl}}=1 \mathrm{~g} / \mathrm{L}$. It is obvious in Figure 10 that current efficiency exceeds $100 \%$ (119-389\%), which means that in addition to electrochemical reactions some chemical reactions may take place. As expected from previous researches $[20,26]$, for higher color removal efficiency from wastewater, the current efficiency decreases. 


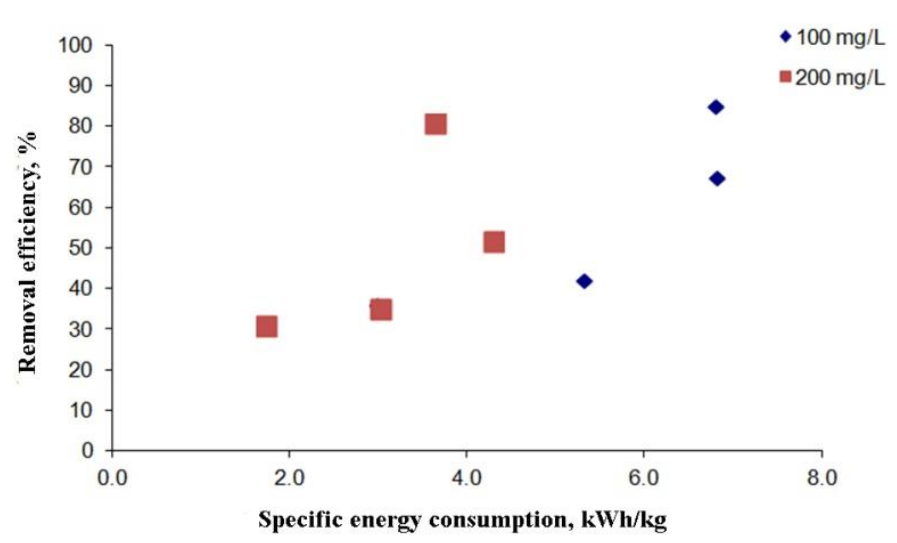

Figure 11. Energy consumption as a function of color removal efficiency

Dependence of energy consumption on the color removal efficiency at different initial concentrations is shown in Figure 11 . At initial concentration, $\nu_{0}=400 \mathrm{mg} / \mathrm{L}$, energy consumption (per kilogram of dye removed from the waste water) at removal efficiency, $E_{\mathrm{u}}=54.76 \%$, is $W_{\mathrm{sp}}=3.8021 \mathrm{kWh} / \mathrm{kg}$ dye $\left(j=10 \mathrm{~mA} / \mathrm{cm}^{2}, t=600 \mathrm{~s}, \gamma_{\mathrm{NaCl}}=1 \mathrm{~g} / \mathrm{L}\right)$.

\section{Conclusions}

This study shows that EC with Fe anode is the efficient process for removing the mixture of azo dyes from waste water. The process is influenced mostly by concentration of supporting electrolyte $(\mathrm{NaCl})$, dye concentration, current density and reaction time. For $80.64 \%$ color removal efficiency at initial dye concentration of solution $\gamma_{0}=200 \mathrm{mg} / \mathrm{L}\left(j=10 \mathrm{~mA} / \mathrm{cm}^{2}, \quad \gamma_{\mathrm{NaCl}}=1 \mathrm{~g} / \mathrm{L}\right)$, up to $3.64 \mathrm{kWh} / \mathrm{kg}$ dye of energy has been consumed.

Acknowledgements: This work was supported in part by the Ministry of Science and Technology of the Republic of Srpska under Project 19/6-020/961-171/14.

\section{References}

[1] F. M. D. Chequer, J. P. F. Angeli, E. R. A.Ferraz, M. S. Tsuboy, J. C. Marcarini, M. S. Mantovani, D. P. De Oliviera, Mutation Research/Genetic Toxicology and Environmental Mutagenesis, 676(1-2) (2009) 83-86.

[2] F. P. Van Der Zee, G. Lettinga, J. A. Field, Chemosphere 44(5) (2001) 1169-1176.

[3] E. Fernando, PhD thesis, University of Westminster, Faculty of Science and Technology, 2014.

[4] Z. Yu, X. Wen, Int. Biodeterior. Biodegrad. 56(2) (2005) 109-114.

[5] P. Rajaguru, L. J. Fairbairn, J. Ashby, M. A. Willington, S. Turner, L. A. Woolford, N. Chinnasamy, J. A. Rafferty, Mutation Research 444(1) (1999) 175-180.

[6] G. A. Umbuzeiro, H. Freeman, S. H. Warren, F. Kummrow, L. D. Claxton, Food and Chemical Toxicology 43(1) (2005) 49-56.

[7] A. Pandey, P. Singh, L. Iyengar, International Biodeterioration \& Biodegradation 59(2) (2007) 73-84.

[8] C. A. Martinez-Huitle, E. Brillas, Applied Catalysis B: Environmental 87(3-4) (2009) 105-145.

[9] E. Bagda, E. Bagda, Journal of Environmental Protection and Ecology 13(2) (2012) 517-531.

[10] C. Zaharia, D. Suteu, Journal of Environmental Protection and Ecology 15(4) (2014) 16801689.

[11] G. Demir, Journal of Environmental Protection and Ecology 11(1) (2010) 7-19.

[12] B. N. Malinovic, M. G. Pavlovic, Journal of Electrochemical Science and Engineering 6(1) (2016) 67-75. 
[13] C. E. Barrera-Díaz, G. Roa-Morales, P. B. Hernández, C. M. Fernandez-Marchante, M. A. Rodrigo, Journal of Electrochemical Science and Engineering 4(4) (2014) 285-296.

[14] G. Chen, Separation and Purification Technology 38(1) (2004) 11-41.

[15] P. Kariyajjanavarl, J. Narayanal, Y. A. Nayaka, Hydrology Current Research 2(1) (2011) 1-7.

[16] A. Alaton, I. Kabdasli, Y. Sahin, The Open Environmental \& Biological Monitoring Journal 1(1) (2008) 1-7.

[17] J. Zhou, C. Deng, S. Si, Y. Shi, X. Zhao, Electrochim. Acta 56(5) (2011) 2062-2067.

[18] K. Xie, L. Sun, C. Wang, Y. Lai, M. Wang, H. Chen, C. Lin, Electrochimica Acta 55 (24) (2010) 7211-7218.

[19] A. Molina, F. Martinez-Ortiz, E. Laborda, R.G. Compton, Electrochimica Acta 55 (18) (2010) 5163-5172.

[20] B. Malinovic, M. G. Pavlovic, Yucorr XVII, Proceeding, Tara, Serbia, 2015, 85-93 (in Serbian).

[21] N. Mameri, A. R. Yeddou, H. Lounici, D. Belhocine, H. Grib, B. Bariou, Water Research 32(5) (1998) 1604-1612.

[22] Synthesia a.s. Safety Data Sheet. From http://dyes.synthesia.eu/organics-dyes/textiledyes/ostalan-black-sr (2015, June 20).

[23] AMERICAN PUBLIC HEALTH ASSOCIATION (APHA). Standard Methods of Water and Wastewater. $18^{\text {th }}$ ed. American Public Health Association, American Water Works Association, Water Environment Federation publication. APHA, Washington D.C., 1992.

[24] K. I. Popov, Periodično promenljivi režimi u elektrohemijskom taloženju metala, in: M. G. Pavlović, A.Dekanski [eds.] Primena pulsnih režima u galvanskoj tehnici: IHTM - Centar za elektrohemiju, Belgrade, Serbia, 1992, 49-73 (in Serbian).

[25] B. Malinovic, M. G. Pavlovic, J. Mandic, Glasnik hemičara, tehnologa i ekologa Republike Srpske (9) (2013) 21-27 (in Serbian).

[26] B. N. Malinovic, M. G. Pavlovic, N. Halilovic, Journal of Environmental Protection and Ecology 16(4) (2015) 1273-1281.

C2017 by the authors; licensee IAPC, Zagreb, Croatia. This article is an open-access article distributed under the terms and conditions of the Creative Commons Attribution license (http://creativecommons.org/licenses/by/4.0/) 